\title{
Asia's Land Down Under: the Socceroos and the 2015 Asian Cup
}

\section{Alan Bairner (Loughborough University, UK)}

Email: A.E.S.Bairner@lboro.ac.uk

\begin{abstract}
On 31st January 2015, Australia's men's association football team (the Socceroos) won the Asian Cup for the first time, beating South Korea 2-1 after extra time in the final match played at Stadium Australia in Sydney. The victory in Sydney was a major milestone in two long-running processes - first, the ever closer relationship between Australia and Asia and second, the evolving status in Australian society of football, or soccer as it continues to be known by those Australians who have long regarded it as a 'wicked foreign game' (Hay, 2006). In terms of assessing Australia’s status as Asian, although part of problem may lie with the Asian Football Confederation's definition of Asia, it is membership of that federation that has done more than any amount of trade relations and labour migration to give global public credence to the idea that Australia is possibly Asian and almost certainly AsianPacific.
\end{abstract}

Keywords: Australia; football/soccer; Asian Football Confederation (AFC)

\section{Introduction}

In 1995, Stephen Wagg (1995: 153) wrote that Australian football 'though not very significant in the world scene, is a giant in the Oceania area, with only New Zealand to offer serious opposition’. On 31st January 2015, Australia’s men’s association football team (the Socceroos) won the Asian Cup for the first time, beating South Korea 2-1 after extra time in the final match played at Stadium Australia in Sydney. Clearly much had happened in the intervening period since Wagg passed his judgment. 
The victory in Sydney was a major milestone in two long-running processes - first, the ever closer relationship between Australia and Asia and second, the evolving status in Australian society of football, or soccer as it continues to be known by those Australians who have long regarded it as a 'wicked foreign game' (Hay, 2006). Neither process has been completed as yet but the current situation is well worth consideration by readers of a journal, the initial commitment of which was to publish work about East Asia and by East Asian scholars albeit under the broader banner of the Asia Pacific region from which it is difficult, if not impossible, to exclude Australia and New Zealand (Bairner, 2012). For example, as Milner and Johnson (2001: 13) have argued, 'The question that must concern Australians is where we are positioned in the context of the contending ideas of "Asia”, which are emerging in the region today'. The question is difficult if not impossible to answer for the simple reason that as Carniel (2012: 2406)) notes, 'Historically, Australia has had an ambiguous relationship with Asia both as a concept and as a region'.

\section{Australia and Asia}

According to Hemmer and Katzenstein (2002: 575), 'In the aftermath of World War II, the United States attempted to create and organize both a North Atlantic and a Southeast Asian region. The institutional forms of these regional groupings, however, differed dramatically'. The Southeast Asian Treaty Organization (SEATO) was established in 1954. One thing that the two had in common, however, was that neither existed as a geographical fact. 'Both were politically constructed' (Hemmer and Katzenstein, 2002: 587). That much is particularly evident in the case of South East Asia in the fact that only two of SEATO’s members, Thailand and the Philippines, were geographically part of Southeast Asia. The other member 
states were Australia, France, the United Kingdom, New Zealand, Pakistan and the United States.

In a marked shift of direction, the Association of South East Asian Nations (ASEAN) was formed in August 1967, the founding members being Indonesia, Malaysia, the Philippines, Singapore and Thailand. They were subsequently joined by Brunei, Cambodia, Myanmar (Burma) and Vietnam. In 1997, as a result of the Plus 3 process, closer ties were forged with the People’s Republic of China, Japan and South Korea.

In a further change of focus, in April 2015, the foreign ministers of ten member states of ASEAN 'decided to stretch the definition of East Asia beyond its geographical limits by agreeing that several countries outside the East Asian region could participate in the inaugural East Asian Summit’ (Richardson, 2005: 351). These included India, New Zealand and Australia. In the case of the latter, how things had changed since the days when it was an ‘anxious nation’ confronted by the rise of Asia in the years between 1850 and 1939 and when considerable energy was invested in establishing that the country was neither Aboriginal nor Asian (Walker, 2012). Indeed, 'Australia’s racial and spatial anxiety has manifested itself in various ways but none appears more focused on Asia than its notorious White Australia policy’ which was formalised in the Immigration Restriction Act of 1901 (Carniel, 2012: 2408). Official and popular attitudes towards the Oceanic nations were no better.

Nevertheless, by the 1930s, Asia-Pacific themes were being discussed, amongst them the desirability and viability of Australia forging closer links with the region. Resistance to such a development has never been solely to be found in Australia. As Richardson (2005: 352) notes, 'ASEAN's decision to take a more open approach on membership of the EAS was a rejection of the exclusive attitude of the long-serving former Malaysian Prime Minister 
Mahathir bin Mohammad'. This in turn raises questions about what we even mean now by the word Asia.

Writing in 2001, Milner and Johnson (2001: 1) observed that 'The signification of “Asia” is, in fact, in contest and it is those who would identify themselves as "Asians", who have most recently been at the forefront of the defining process'. Moreover, this process is by no means new. At the beginning of the twentieth century, the Japanese art historian, Okakura Tenshin, announced that 'Asia is one’ and, for many years, the Nobel winning Indian poet, Rabindranath Tagore 'devoted energy to the task of promoting a renascent Asian civilization' (Milner and Johnson, 2001: 2). Needless to say, Australia was scarcely on the radar of these Asian intellectuals. But how realistic is it in any case to regard what has long been defined as Asia as being one and indivisible? Perhaps an examination of football in the region can help us to address, if not necessarily solve this conundrum

\section{Football in Australia}

In 2006, Roy Hay (2006: 165) wrote that 'Soccer...is not the main code of football in any state in Australia, but is probably the second in most states if measured by spectator attendance or participation'. Arguably the challenge for association football in New Zealand, another country which may or may not be Asian depending on which criteria are used, where ‘the sport has to also assert itself against rugby union’s much older, more sedimented, articulation to nationalism and masculinity' (Bruce and Stewart, 2014: 11). In Australia, according to Stell and Salisbury (2015: 246), 'Despite the lack of press coverage, there is no denying that in the late 1960s and early 1970s football had emerged in Australia as a new national challenge’. However, as Nicholson et al (2014: 2) argue, ‘Any discussion of Australian soccer must necessarily take into account the narratives of Australian nationalism'. 
In this respect, it has been association football's multicultural character that has rendered it distinct from the other football codes and, in the eyes of some, distinctly un-Australian. As Hughson (1997: 242) suggested, 'The development of soccer in Australia was tied very closely to the history of immigration’. Indeed, according to Hallinan and Heenan (2013: 762), 'it was not until 2003 that "the ethnic game” was laid to rest'.

The so-called 'ethnic game' emerged when the old-style amateur administrators of the Australian Soccer Association (ASA) were challenged by representatives of new migrant groups, 'whose team names reflected their origins just as clearly as did those of the previous generations’ (Hay, 2011: 835). A breakaway movement that had begun in Sydney quickly spread and the Australian Soccer Federation (ASF) was established leading to internal conflict and Australia's suspension from FIFA. The game continued to make relatively slow progress, however, compared with the other football codes and most commentators explained this by reference to ethnic rivalries.

Whether ethnicity was the problem that many took it to be is open to debate. For example, Stell and Salisbury (2015: 247) argue that 'in the 1970s at least, and in 1974 in particular, football thrives because it is multicultural'. The 1974 World Cup squad, they go on, was 'the epitome of Australia’s concerted immigration programme since 1949’ (p. 253). Fourteen of the twenty players had arrived in Australia through that programme and no match that was played in Germany featured more than two Australian-born players at any one time.

With Australia having reached the FIFA World Cup Finals for the first time and a national league, the first for any football code in the country, having been established three years later, confidence grew and was just as quickly dashed. New strategies were tried but failed. Soccer Australia (which had taken over from the ASF) and the National Soccer League had proved unable to make the breakthrough that the fans had hoped for and, in 2003, the former was 
replaced by the Football Federation of Australia (FFA), the latter by the A-League. This was to be the era of 'new football' as opposed to 'old soccer' and ethnic tensions would not be allowed to stand in the way, if that is really what they had done in the past. With this in mind, as recently as 2014, the Chief Executive of the FFA, David Gallop, announced that clubs would no longer even be allowed to use ethnic names or logos.

This policy has not been greeted with universal approval. Although Gallop described the new policy as ‘inclusive’, others have claimed that what it represents is 'de-ethnicisation' and that, in Australia, 'the whitewashing of football clubs has a long and shameful history' (Gorman, 2014). The debate is centres on definitions of multiculturalism on the one hand and assimilation on the other. According to Gorman (2014), 'Multiculturalism is not assimilation, not now, not ever' and 'forcing clubs to have Anglicized names is as wrong now as it ever was'.

For Hallinan and Hughson (2009), the reasons that lie behind 'de-ethnicization' have had more to do with politics than with the development of football. They argue that in the late 1990s former Prime Minister John Howard’s 'brand of nationalism railed against a multicultural society based on pluralistic values (p. 2).

Against a backdrop of arguments about what it means to be Australian, the new A-League itself kicked off in late August 2005. The A-League - sponsored by Hyundai, the South Korean car manufacturer - is currently contested by 10 teams: nine from Australia and one from New Zealand. A total of 13 teams have competed at some stage in the league's short history. Only four of these clubs - Adelaide United, Brisbane Roar (as Queensland Lions), Newcastle Jets, and Perth Glory - existed before the A-League was formed. Hallinan and Hughson (2009) claim that the old fan base, which had been rooted in ethnicity, had now been destroyed. In the process, although the Hyundai A-League has been popular with many 
fans and certain commentators, 'the erasure of the mark of un-Australian from soccer, so gleefully greeted by some, should be lamented by Australians concerned that cultural differences be played out naturally rather than quashed by political, commercial and administrative fiat' p. 6). More important, however, for the future of football in Australia, according to Hay (2011), was the acceptance of Australia into the Asian confederation at last and for that, the A-League had been an essential prerequisite.

\section{Australia and the Asian Football Confederation}

Although Australia has experienced increasingly closer relationships with Asian countries, not least since the accession of the UK to the European Economic Community (subsequently the European Union), given the high visibility of sport, both globally and in Australia in particular, joining the AFC represented a symbolically significant decision even though soccer/football is still viewed with suspicion by many Australian sports fans. As early as the 1950s, Australia was considered by FIFA to be part of the Asian zone. However, as noted above, the country was suspended by FIFA between 1960 and 1963 as a result of conflict between the ASA and the ASF which was also a conflict between respectively British/Australian administrators and those who represented the interest of more recently arrived ethnic groups which were having a considerable influence on the game (Wagg, 1995).

A precondition for Australia to be admitted to the AFC was the existence of a corporatized, franchise-based A-League which, as we have seen, has meant separating the game at the elite level from its multicultural and ethnic roots to 'a corporate assimilationist model' (Hallinan and Heenan, 2013: 756). Of equally neo-liberal importance is the fact that despite its difficult past, ‘soccer now stands central to Australia's standing in the “Asian Century”, promising to be a cultural, economic and geopolitical commodity’(Pagic, 2013: 735). One need not be a 
Marxist to understand that money talks and, as Hallinan and Heenan (2013: 757) suggest, membership of the AFC merely serves to reinforce that 'all that binds Australia to Asia is economic opportunism and in football's case, the endless quest for a bigger market acquired through a formal realignment from Oceania to the AFC'. The cynic would add that this is what ties most countries to others in the era of global capitalism. The move was announced at the beginning of 2006 and finalised at the end of that year's World Cup Finals. It had taken Australia over 40 years 'to achieve its goal of joining the geographical zone to which it had

\section{Conclusion}

Two questions remain to be answered and this can only be done in time. First, has the Asian Cup triumph finally consolidated football’s status in Australia's sporting culture? Certainly sections of the media thought so.

...winning the tournament on home turf has given both the team and the game the boost in Australia many commentators have argued for years that it needs and deserves. (Clark, 2015)

Australia's historic Asian Cup triumph is expected to spark an explosion in junior registrations as children follow in the footsteps of their Socceroos heroes. (Rolfe and Kinniburgh, 2015)

Football Federation Australia’s forecasting an 8 per cent growth in outdoor club soccer sign-ups this season on the back of the heroics of Tim Cahill and co. (Rolfe and Kinniburgh, 2015)

Only time will tell whether these predictions prove correct or not. 
In relation to the central concerns of this journal, however, there is arguably a far more important question. How significant is the Asian Cup triumph in terms of Australia's relationship with Asia in general and the countries of East Asia in particular? One significant obstacle to further progress lies in the fact that 'nations from both central Asia and the Middle East belong to the AFC, and... new iterations of anti-Asian and now anti-Arab sentiment undoubtedly affect Australia’s reputation in dealing with these nations' (Carniel, 2012: 2410). According to Carniel (2012: 2410), 'Despite the elasticity or vagueness of the term Asia, it remains difficult to extend its meaning to incorporate Australia’. Indeed, Carniel argues that 'Both Australia and Asia require a significant shift in their thinking - to see themselves as belonging to the same neighbourhood, if not family - in order for regional relations to progress positively'. On the other hand, that is probably just as true of many countries which are not only members of the AFC but also less contentiously located in Asia - the Gulf States, for example, the countries of the Middle East, and those which comprise the Indian subcontinent. Arguably, Australia, and perhaps New Zealand too, is as Asian as any of these. Hallinan and Heenan (2013: 764) argue that 'Australia has not changed so much from “Oceanic” to “Asian” but has leveraged an opportunity to re-align Confederation membership (and all the nascent commercial opportunities) from OFC to the AFC'. The economic imperative is demonstrably important but there is nothing exceptional about Australia in this respect. Within the area that is most widely accepted to be authentically Asian, Taiwan seeks trading opportunities with the People’s Republic of China despite lingering cross-strait tension and not only do South Korea and Japan enjoy economic relations, they even cohosted a FIFA World Cup.

Ironically, in terms of assessing Australia's status as Asian, although part of problem may lie with the AFC's definition of Asia, it is membership of that federation that has done more than 
any amount of trade relations and labour migration to give global public credence to the idea that Australia is possibly Asian and almost certainly Asian-Pacific. It is equally ironic, however, that the A-League which aided Australia's accession to the AFC has been seen by some as reflecting an outdated and parochial understanding of what Australia is. The future will be nothing if not interesting.

\section{References}

Bairner, A. (2012). Sport, Social Science and the Asia Pacific. Asia Pacific Journal of Sport and Social Science, 1 (1), 1-7.

Bruce, T. and Stewart, A. (2014). As Kiwi as? Contestation over the place of men's football in New Zealand culture. Soccer and Society, DOI: 10.1080/14660970.2014.963308.

Carniel, J. (2012). Reflections on Race, Regionalism and Geopolitical Trends via Australian Soccer. International Journal of the History of Sport, 29 (17), 2405-2420),

Clarke, H. (2015). Australia Wins Asian Cup, Discovers Soccer. The Diplomat, 3 February. http://thediplomat.com/2015/02/australia-wins-asian-cup-discovers-soccer/

Gorman, J. (2014). FFA Cup draw darkened by attacks on clubs’ identities. The Guardian, 27 June (http://www.theguardian.com/football/blog/2014/jun/27/ffa-cup-draw-national-clubidentity-policy). Accessed 17 February, 2015.

Hallinan, C. and Heenan, T. (2013). Australia, Asia and the new football opportunity. Soccer and Society, 14 (5), 751-767.

Hallinan, C. and Hughson, J. (2009). The beautiful game in Howard’s 'Brutopia': football, ethnicity and citizenship in Australia. Soccer and Society, 10 (1), 108. 
Hay, R. (2006). ‘Our Wicked Foreign Game’: Why has Association Football (Soccer) not become the Main Code of Football in Australia. Soccer and Society, 7 (2-3), 165-186.

Hemmer, C. and Katzenstein, P. J. ((2002). Why is There No NATO in Asia? Collective Identity, Regionalism, and the Origins of Multiculturalism. International Organization, 56 (3), 575-607.

Hughson, J. (1997). The Bad Blue Boys and the ‘Magical Rediscovery’ of John Clarke. In G. Armstrong and R. Giulianotti (Eds.), Entering the Field. New Perspectives on World Football (pp. 239-259). Oxford: Berg.

Milner, A. and Johnson, D. (2001). The Idea of Asia. Faculty of Asian Studies, Australian National University (https://digitalcollections.anu.edu.au/bitstream/1885/41891/1/idea.html) Accessed 12 February 2015.

Nicholson, M. Sherry, E. and Osborne, A. (2014). Negotiating national identity through loss: Australian newspaper coverage of the 2010 FIFA World Cup. Soccer and Society, DOI: $\underline{10.1080 / 14660970.2014 .980739 .}$.

Pagic, Z. (2013). 'A' is for Australia: New Football’s billionaires, consumers and the 'Asian Century’. How the A-League defines the new Australia. Soccer and Society, 14 (5), 734-750. Richardson, M. (2005). Australia-Southeast Asia relations and the East Asian Summit. Australian Journal of International Affairs, 59 (3), 351-365.

Rolfe, P. and Kinniburgh, C. (2015). Socceroos Asian Cup triumph to spark and explosion in junior players. Herald Sun, 7 February.

http://www.heraldsun.com.au/news/victoria/socceroos-asian-cup-triumph-to-spark-explosionin-junior-players/story-fni0fit3-1227211580915. Accessed 14 February 2015. 
Stell, M. and Salisbury, C. (2015). 'It’s Bigger than the Olympics’: changing Australia through football and the 1974 FIFA World Cup. Soccer and Society, 16 (2-3), 245-258.

Wagg, S. (1995). Giving the Game Away. Football, Politics and Culture on Five Continents. Leicester: Leicester University Press.

Walker, D. (2012). Anxious Nation: Australia and the rise of Asia 1850-1939. Crawley, WA: UWA Publishing. 